\title{
Prediction of the Mechanical Performance of High-Strength Concrete Containing Biomedical Polymeric Waste Obtained from Dialysis Treatment
}

\author{
Saman Rahimireskati*(D), Kazem Ghabraie (D), Estela Oliari Garcez (D) and Riyadh Al-Ameri *(D) \\ School of Engineering, Deakin University, Waurn Ponds, VIC 3216, Australia; k.ghabraie@deakin.edu.au (K.G.); \\ estela.o@deakin.edu.au (E.O.G.) \\ * Correspondence: s.rahimireskati@deakin.edu.au or saman.r.r.ac@gmail.com (S.R.); \\ r.alameri@deakin.edu.au (R.A.-A.)
}

check for

updates

Citation: Rahimireskati, S.; Ghabraie,

K.; Garcez, E.O.; Al-Ameri, R.

Prediction of the Mechanical

Performance of High-Strength

Concrete Containing Biomedical

Polymeric Waste Obtained from

Dialysis Treatment. Appl. Sci. 2021, 11,

2053. https://doi.org/10.3390/app

11052053

Academic Editor: Jorge de Brito

Received: 22 January 2021

Accepted: 21 February 2021

Published: 25 February 2021

Publisher's Note: MDPI stays neutral with regard to jurisdictional claims in published maps and institutional affiliations.

Copyright: (c) 2021 by the authors Licensee MDPI, Basel, Switzerland. This article is an open access article distributed under the terms and conditions of the Creative Commons Attribution (CC BY) license (https:/ / creativecommons.org/licenses/by/ $4.0 /)$.
Abstract: Since between 1.5 and $8 \mathrm{~kg}$ (400 kg/patient/year) of biomedical polymeric waste (BPW) is usually discarded by landfilling or combusting after each dialysis treatment, this study provides evidence for safe and environment-friendly utilisation of BPW, sourced from dialysis treatment and donated by the health and industrial partners, by incorporating it in high-strength concrete. Moreover, the paper aims to provide engineers, designers, and the construction industry with information regarding the mechanical performance of high-strength concrete containing BPW, and the susceptibility of the current international codes and standards on the prediction of the mechanical performance. A new concrete mix design incorporating BPW was proposed and verified by several trial mixes. Three Soft, Hard, and Hybrid BPW were added to the conventional high-strength concrete in different percentages ranging from $1.5 \%$ to $9 \%$ by weight of cement. Afterwards, the fresh and hardened concrete properties, namely slump, density, compressive strength, tensile strength, modulus of elasticity, and Scanning Electron Microscopy (SEM), were investigated, and existing prediction models were employed to verify their suitability for the new concrete. Generally, adding Hybrid BPW resulted in better mechanical performance than soft or hard BPW addition, while eliminating the waste separation phase. The results also showed that the mechanical performance of $\mathrm{BPW}$-containing concrete is predictable by current codes, addressing possible engineering design limitations. New higher accuracy regression-based models were also proposed to reach better engineering interpretations.

Keywords: green structural concrete; biomedical polymeric waste; mechanical properties; predictive models

\section{Introduction}

To meet the sustainability measures and due to the increasing demand for medical services worldwide, managing biomedical waste is becoming more crucial [1-3]. From the environmental perspective, about $80 \%$ of published lifecycle analysis studies, compared to mechanical recycling and incineration methods, recommend mechanical recycling as an advantage [4,5]. Moreover, among different mechanical recycling approaches, employing various types of waste in forms of aggregate and fibre in the production of cementitious materials is considered as an environment-friendly, safe, and economical disposal approach [6-9].

Nephrology and particularly dialysis, among healthcare practices, are of the highest biomedical polymeric waste (BPW) producers. Between 1.5 and $8 \mathrm{~kg}$ (400 kg/patient/year) of BPW is usually discarded by landfilling or combusting after each treatment [10]. Since the majority of types of polymers are not biodegradable, they accumulate in landfills. Previous studies revealed that $49-60 \%$ of BPW is disinfected by incineration, $20-37 \%$ by autoclave method, and $4-5 \%$ is treated using other technologies [11]. Although other 
methods like autoclaving and microwaving are considered more environmentally friendly than incineration, the waste does not change in volume after treatment. It should be retreated by incineration that increases the disposal cost and makes the disinfection process redundant $[12,13]$. Combusting by-products are also highly carcinogenic, leading to human reproductive diseases and damage to the excretory and reproductive systems [14,15]. On the other hand, considering the literature in the case of BPW-containing concrete, it is necessary to study the incorporation of BPW in structural high-strength concrete as most of the previous studies investigated using polymeric waste in normal strength concrete, and there is a need for more strength (AS 3600 [16], ACI 318-11 [17]) regarding the structures exposed to severe environments. Besides, separating the BPW based on their softness (polypropylene, low-density polyethylene, nylon, and silicon), hardness (polyvinyl chloride, high-density polyethylene) [10], and combinations (hybrid) can be of high importance when studying the new concrete properties. The waste separation process can be eliminated if the Hybrid BPW-containing concrete can be proven to have a better performance. There is also a scarcity of information regarding evaluating and comparing the properties of BPW-containing high-strength concrete with standard codes for engineering design purposes.

Concerning the concrete's workability containing polymeric waste, almost all previous works confirm a decrease in the slump [18-26]. However, Saikia and de Brito [27], who have investigated concrete containing three shredded fine range, coarse range, and heattreated pellet shapes, have reported an increase in the slump by employing heat-treated pellet shape plastics and a decrease in the slump by using fine and coarse shredded types. Moreover, regarding different hardened properties of concrete containing polymeric waste, Kaur et al. [28] utilised the BPW ash as filler in concrete. It resulted in higher compressive and tensile strength due to its pozzolanic property. Some other studies also employed the BPW as ash in mortars and concrete and recommended it as a pozzolanic material and filler. However, there are still several environmental concerns for that purpose [29-31]. Ghernouti et al. [27] Al-Hadithi and Hilal [28], Marthong and Sarma [29], Kandasamy and Murugesan [30], Alhozaimy and Shannag [31], and Yang et al. [32] also reported an increase in the compressive strength of concrete by incorporating polymers as fibres. Investigating the tensile strength, researchers also reported a reduction in the tensile strength of concrete by employing different types of polymeric waste materials as aggregate in concrete [18,33-37]. Modulus of elasticity of concrete containing polymeric wastes was also reported to decrease by incorporating polymers in concrete [34,38-43]. Al-Hadithi and Hilal [28] and Ruiz-Herrero et al. [44] also reported a systematic reduction in the density of concrete containing polymeric wastes. They attributed it to the low density of the waste particles when compared to sand. Moreover, several studies compared the mechanical properties of concrete containing polymeric materials. They introduced some equations for the compressive strength, tensile strength, modulus of elasticity, and their relations with other properties of concrete [35,45-50].

As mentioned before, to address the limitations in the literature and to pave the way for safe and environment-friendly disposal of BPW, and also to pave the way of using $\mathrm{BPW}$-containing high-strength concrete in the construction industry, the fresh properties and the mechanical performance of high-strength concrete containing BPW are investigated. Afterwards, results are compared with predictive formulae of international codes and other proposed relationships to verify their suitability for BPW-containing high-strength concrete. In the end, new predictive formulae based on the experimental results are introduced to gain more accuracy. 


\section{Experimental Program}

\subsection{Material}

\subsubsection{Biomedical Polymeric Waste}

The disinfected BPW provided by Fresenius Medical Care Australia [51,52] was carefully inspected and hollow filter fibres were separated by sieving and vacuuming due to their low strength (Figure 1).

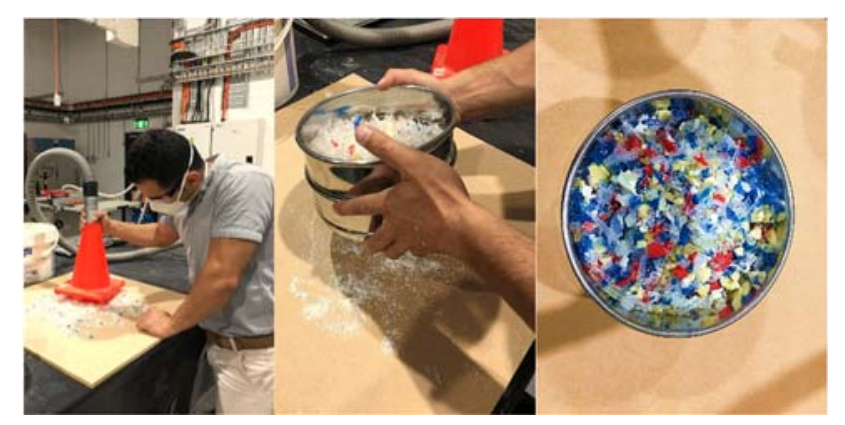

Figure 1. Separating filter fibres from biomedical polymeric waste (BPW) by sieving and vacuuming.

Afterwards, the inspected BPW was divided into three groups of hard (polyvinyl chloride, high-density polyethylene), soft (polypropylene, low-density polyethylene, nylon, and silicon) [10], and hybrid (a 50\% combination of soft and hard BPW). Sieve analysis was then conducted according to AS 1141.11.1 [53]. Figures 2 and 3 illustrate the sieve analysis results and overall view of different shapes (rounded, irregular, elongated, and flaky) and sizes of BPW, respectively.

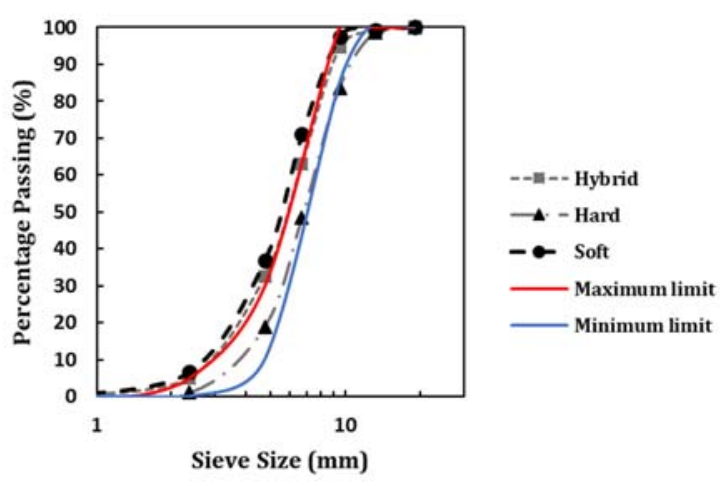

Figure 2. Sieve analysis of BPW. 


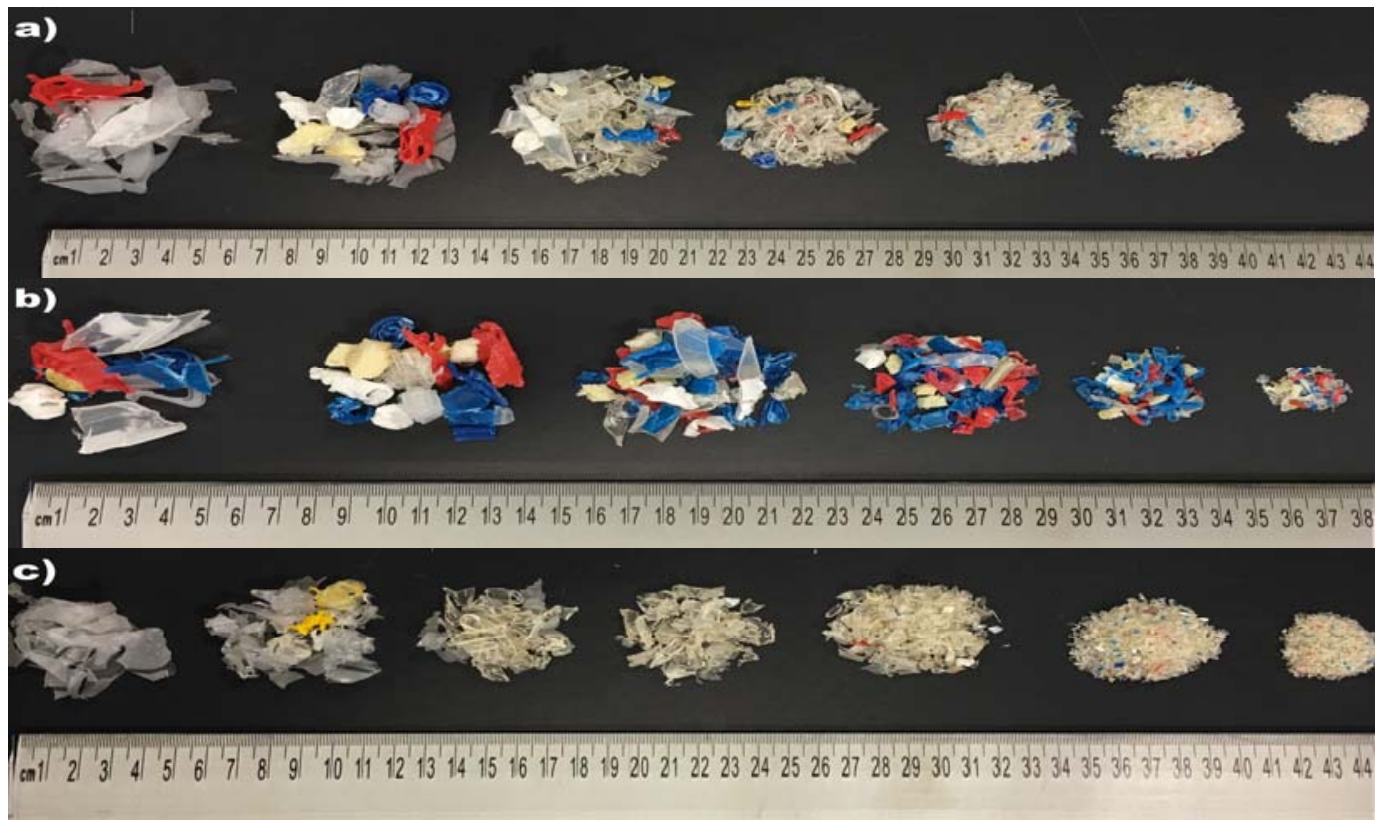

Figure 3. General view of shape and size of the BPW after sieving: (a) Hybrid, (b) hard, (c) soft.

\subsubsection{Natural Aggregate}

The single-sized, coarse, crushed basalt aggregate, provided from Anakie quarry, Victoria, Australia, with the maximum size of $14 \mathrm{~mm}$ and the saturated surface dry particle density (SSD) of $2670 \mathrm{~kg} / \mathrm{m}^{3}$ has been used to keep the concrete's uniformity and prevent segregation after adding BPW particles. Moreover, the sand with the particle density (SSD) of $2590 \mathrm{~kg} / \mathrm{m}^{3}$ was selected along with the coarse aggregate according to AS2758.1 and AS1141 [53,54] standards (Table 1).

Table 1. Properties of the aggregates used.

\begin{tabular}{ccc}
\hline \multirow{2}{*}{ Sieve Size } & \multicolumn{2}{c}{ Percent of Total Passing (\%) } \\
\cline { 2 - 3 } & Fine & Coarse \\
\hline $19 \mathrm{~mm}$ & - & 100 \\
$13.2 \mathrm{~mm}$ & - & 91 \\
$9.5 \mathrm{~mm}$ & - & 22 \\
$6.7 \mathrm{~mm}$ & 100 & 3 \\
$4.75 \mathrm{~mm}$ & 100 & 2 \\
$2.36 \mathrm{~mm}$ & 86 & 1 \\
$1.18 \mathrm{~mm}$ & 65 & 1 \\
600 microns & 44 & - \\
425 microns & 34 & - \\
300 microns & 22 & - \\
150 microns & 5 & - \\
\hline Material finer than 75 microns $(\%)$ & 1 & 0 \\
\hline Water Absorption $(\%)$ & 0.3 & 3.1 \\
\hline
\end{tabular}

\subsubsection{Cement}

The cement used in this study is Eureka general-purpose (GP) Portland cement, which conforms to AS 3972 [55] with the specific gravity of $3150 \mathrm{~kg} / \mathrm{m}^{3}$. 


\subsection{Mix Design and Sample Preparation}

The concrete mix design has been based on the ACI-211 [56] method. Different ratios of $1.5 \%, 3 \%, 6 \%$, and $9 \%$ by weight of cement of each of the three types of BPW have been added to the mixture, with a water/cement ratio of 0.38 (Table 2).

Table 2. Concrete mix design $\left(\mathrm{kg} / \mathrm{m}^{3}\right)$.

\begin{tabular}{cccccc}
\hline $\begin{array}{c}\text { BPW (\%) } \\
\text { (Hybrid, Hard, Soft) }\end{array}$ & Cement & Sand & Gravel & Water & BPW \\
\hline Control & 589.49 & 651.24 & 899.39 & 224.57 & 0 \\
\hline $1.5 \%$ & 589.49 & 651.24 & 899.39 & 224.57 & 8.84 \\
\hline $3 \%$ & 589.49 & 651.24 & 899.39 & 224.57 & 17.68 \\
\hline $6 \%$ & 589.49 & 651.24 & 899.39 & 224.57 & 35.37 \\
\hline $9 \%$ & 589.49 & 651.24 & 899.39 & 224.57 & 53.05 \\
\hline
\end{tabular}

To mix the concrete ingredients, the coarse aggregate and half of the fine aggregate were mixed, and then the BPW particles were added to be mixed with the existing materials. Then, $20 \%$ of the existing water was added to wet the mixing aggregate, and the other half of the fine aggregate and the cement were added. Afterwards, the remaining water was added. The mixing procedure and sample preparation followed after casting 13 mixtures (4 BPW Percentages $\times 3$ BPW types +1 control) and moulding 117 cylindrical specimens of size $100 \times 200 \mathrm{~mm}$, and the specimens were cured for 28 days by submerging in fresh water according to the AS 1012.8.1:2014 [57].

\subsection{Test Methods}

The slump test has been conducted on the fresh mixes to investigate the workability of the concrete according to the AS 1012.3.1:2014 [58]. The density, compressive strength obtained using splitting tensile strength, and modulus of elasticity tests were conducted, employing GEO-CON compression loading frame with the maximum capacity of $3000 \mathrm{kN}$ [59] according to AS 1012.12.1-1998 [60], AS 1012.9:2014 [61], AS 1012.10-2000 [62], and AS 1012.17-1997 [63], respectively. The SEM test was also conducted to better understand the Interfacial Transition Zone (ITZ) between the natural aggregate, BPW, and the cement matrix using the JSM-IT300 [64]. In the end, new regression-based relationships between the mechanical properties of the high-strength concrete containing BPW were introduced using the experimental results. It is also notable to mention that the same correlations were followed in this study regarding the predictive equations introduced by the codes and other researchers. Considering the other relations, the correlations that were the best match to this study's results were obtained.

\section{Results and Discussion}

The obtained experimental results are discussed and analysed in the next sections.

\subsection{Fresh Concrete Properties Slump Test}

The slump test results and their variations compared to the control mixture for different added BPW are shown in Figure 4. 


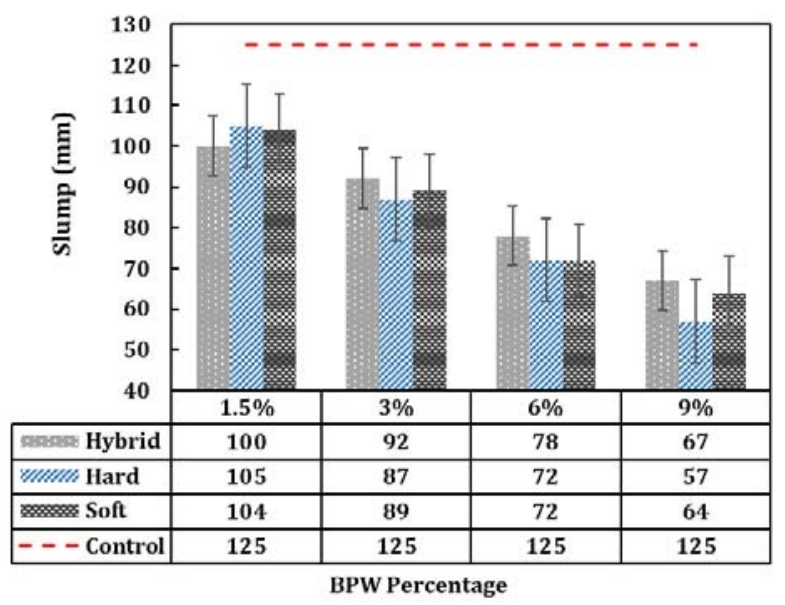

Figure 4. Slump test results.

A decline in the slump was observed with the increase of BPW percentage in concrete. The percentage of BPW is significantly more important than the types of plastic when looking at their impact on the slump test results. However, looking at the impact of different BPW types, it can be generally said that mixtures containing hybrid BPW showed a higher slump and better workability compared with other BPW-containing mixtures. The reduction of slump values can be attributed to the flaky and elongated shapes of BPW particles, as mentioned before, leading to more friction and lower flowability [18].

\subsection{Hardened Concrete Properties}

\subsubsection{Density}

The measured 28-day density of the BPW-containing concrete, and its variation by addition of BPW, is illustrated in Figure 5.

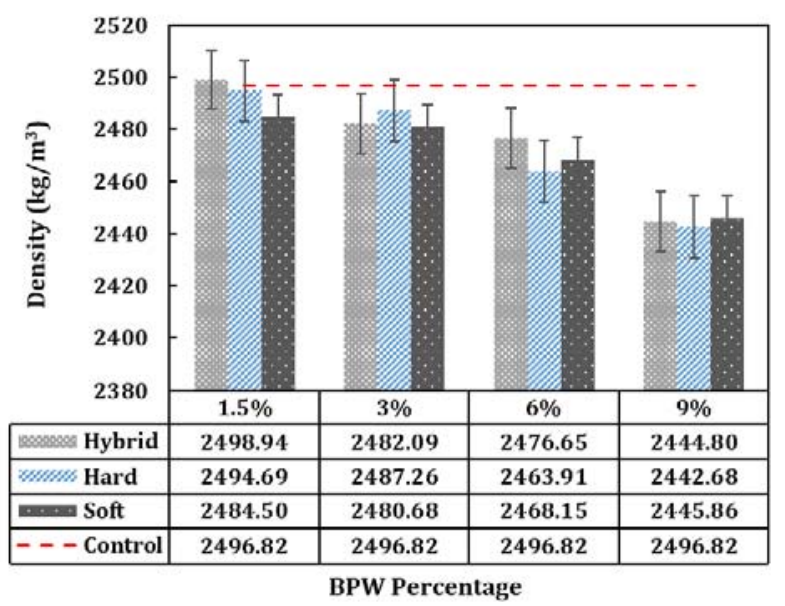

Figure 5. Density values of cast concrete after 28 days of curing.

The density of concrete decreases with BPW, which can be attributed to the lower density of the BPW compared with conventional concrete ingredients. Considering the relative density at each BPW addition percentage, hybrid BPW-containing mixtures showed more density at $1.5 \%$ and $3 \% \mathrm{BPW}$ addition, and the same for hard and hybrid BPWcontaining mixtures at 3\% and 9\% BPW addition, respectively.

\subsubsection{Compressive Strength}

The obtained compressive strength and its variation compared to the control concrete versus different BPW percentages are shown in Figure 6. 


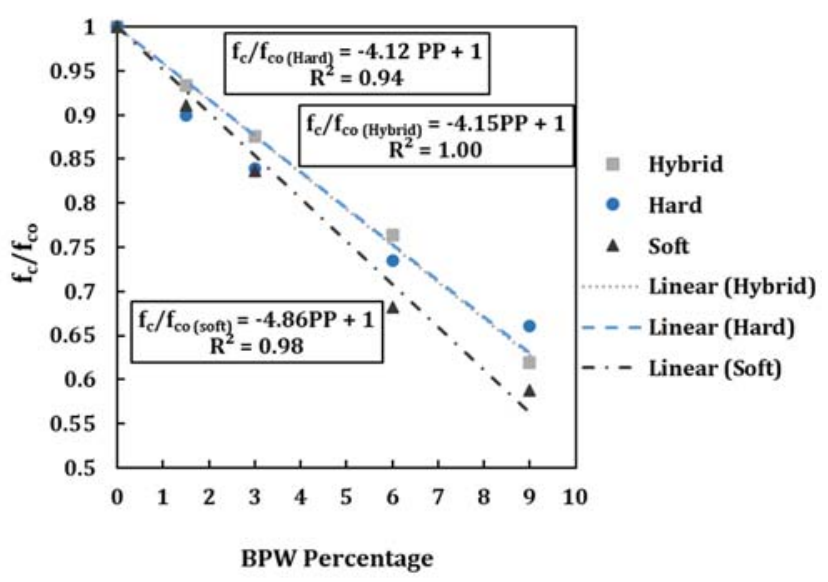

Figure 6. The compressive strength ratio of BPW-containing concrete to control concrete versus BPW percentages.

The compressive strength of the concrete containing all types of BPW was lower than the control mix, and the higher the BPW percentage, the lower the compressive strength. This phenomenon can be attributed to the lower compressive strength of BPW compared to other ingredients and also weaker cohesion and friction at ITZ of BPW and the cement paste compared to the natural aggregate (Figure 7) $[19,38,65,66]$. It is also evident that hard and hybrid BPW reduced the compressive strength less significantly compared to the soft BPW. This difference can be seen clearly in Figure 6, where the reduction in compressive strength is linearly related to the BPW percentage (PP).
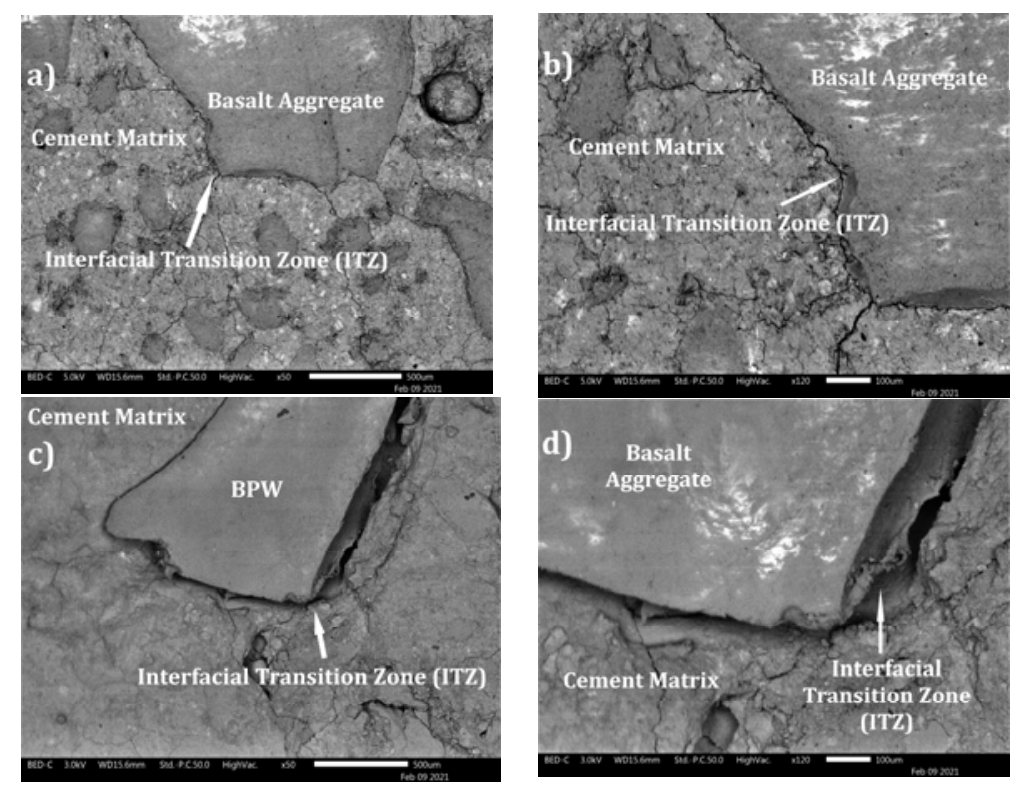

Figure 7. SEM micrographs of the interfacial zone between the natural aggregate $(\mathbf{a}, \mathbf{b})$, BPW $(\mathbf{c}, \mathbf{d})$, and the cement matrix.

The relationship between the compressive strength ratios versus the density ratios of BPW-containing concrete to control concrete is shown in Figure 8. 


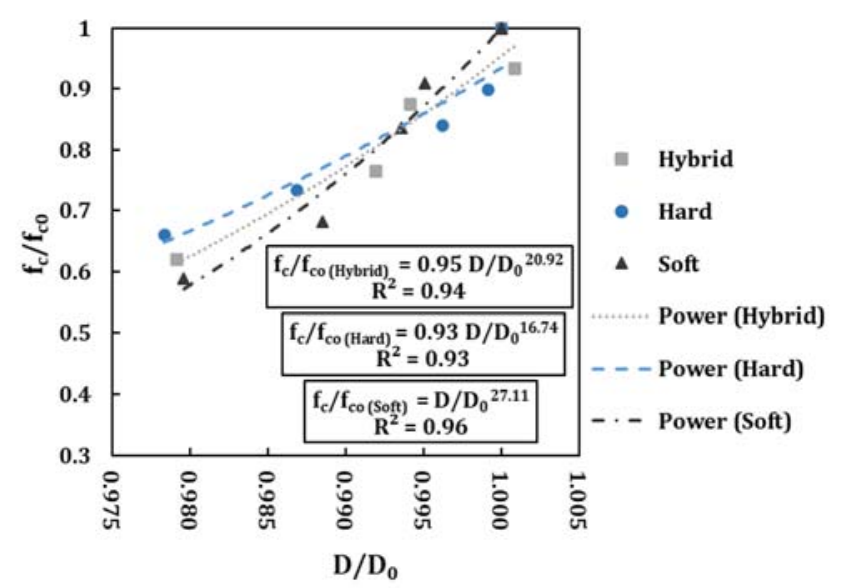

Figure 8. The compressive strength ratios versus the density ratios of BPW-containing concrete to control concrete.

It can be seen that a decrease in compressive strength is accompanied by a decrease in density (D). It is also notable that the relation of compressive strength and density is different for the three BPW types of addition.

\subsubsection{Tensile Strength}

The relationship between the tensile strength ratios of BPW-containing concrete to control concrete and BPW percentages are shown in Figure 9.

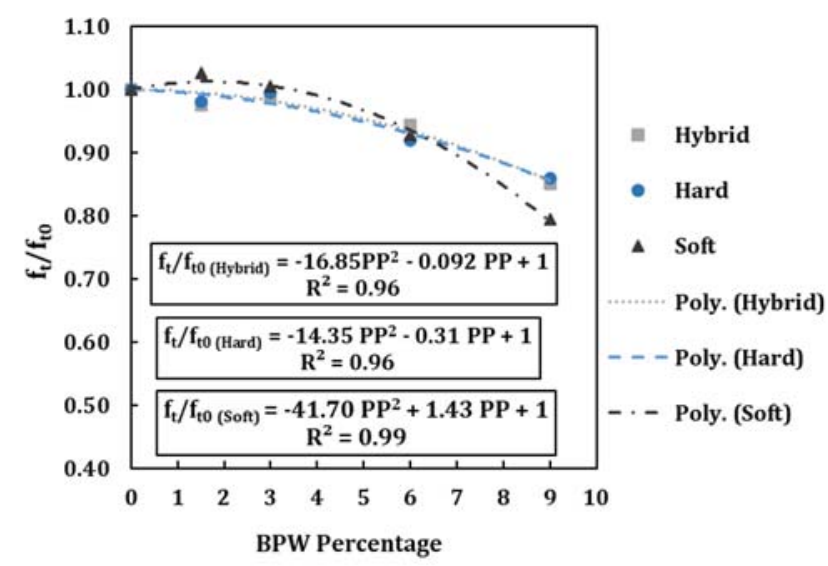

Figure 9. The tensile strength ratio of BPW-containing concrete to control concrete versus BPW percentages.

A quadratic equation is adopted to capture the optimal PP, yielding the maximum tensile strength. Figure 9 confirms that small addition of BPW can maintain tensile strength. However, there seems to be an optimal BPW percentage above which the tensile strength decreases. This behaviour can be attributed to the weaker bond strength between the cement paste and the BPW compared with the natural aggregate (Figure 7) $[18,40,67]$. It also can be observed that the impact of hybrid and hard BPW additions on the tensile strength is almost identical. Besides, although the addition of BPW decreases the tensile strength of concrete at higher percentages, hybrid and hard BPW's addition results in better tensile strength compared to soft BPW.

Besides, most international codes propose a power relation between tensile and compressive strength (see, for example, ACI 363-R08 [68]). Figure 10 demonstrates the power relations found between tensile and compressive strength of different BPW-containing concrete. 


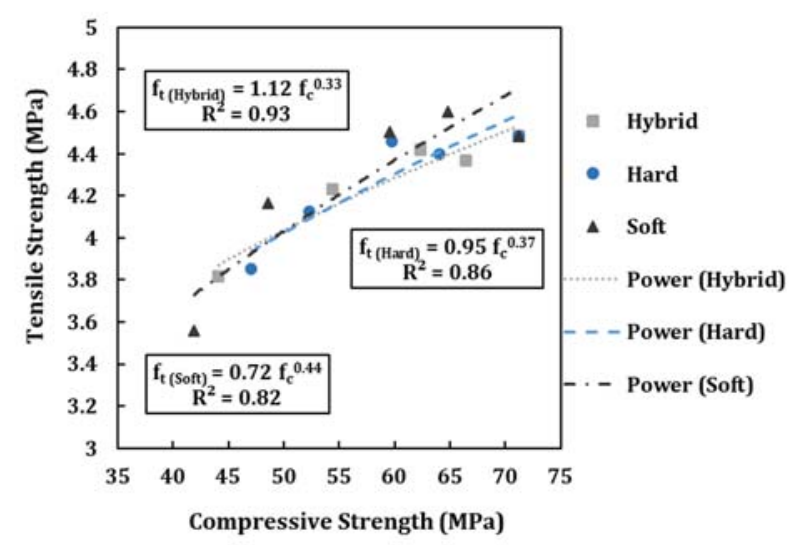

Figure 10. The relation between the tensile strength and compressive strength of concrete containing different percentages and types of BPW.

The power relationship between tensile and compressive strength is not strongly dependent on the BPW type used in the mixtures based on Figure 10. Hence, a general relationship between the tensile and compressive strength of BPW-containing concrete is introduced in Figure 11 and Equation (1) as:

$$
\mathrm{f}_{\mathrm{t}(\mathrm{BPW})}=0.78\left(\mathrm{f}_{\mathrm{c}}{ }^{\wedge}(0.42)\right)
$$
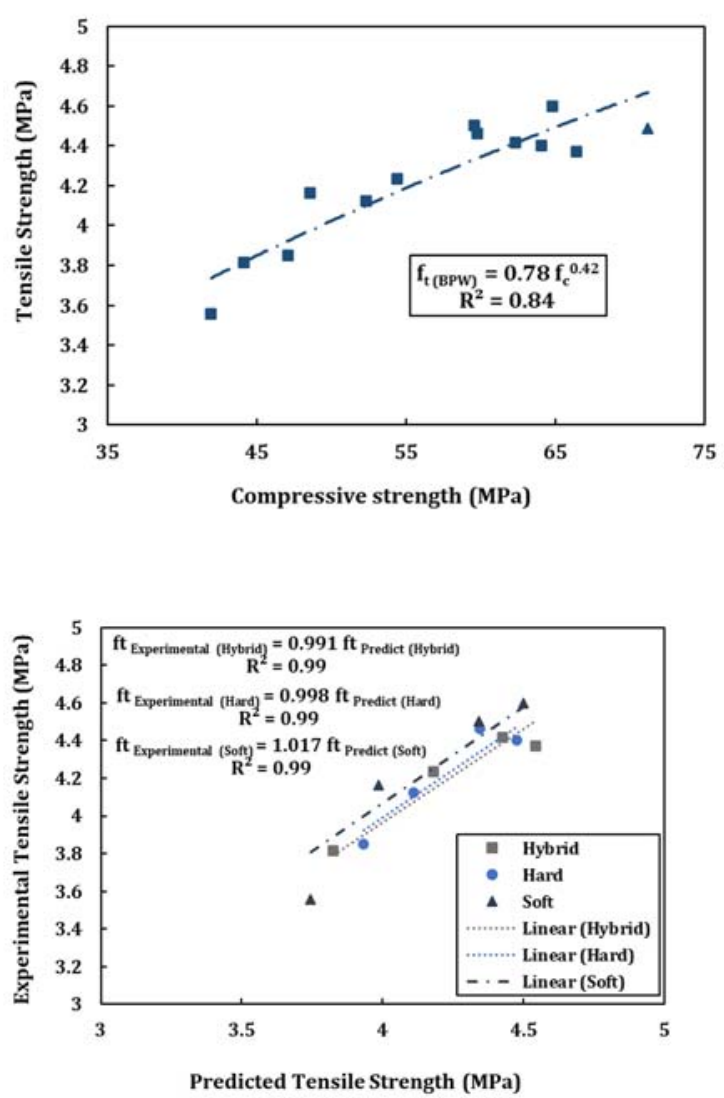

Figure 11. The relation between tensile strength and compressive strength of BPW-containing concrete and correction factors for each type of BPW.

Figure 12 illustrates the ratio of the predicted to experimental tensile strength results, where the predicted results are obtained using the relationship proposed by different international codes, tabulated in Table 3. 

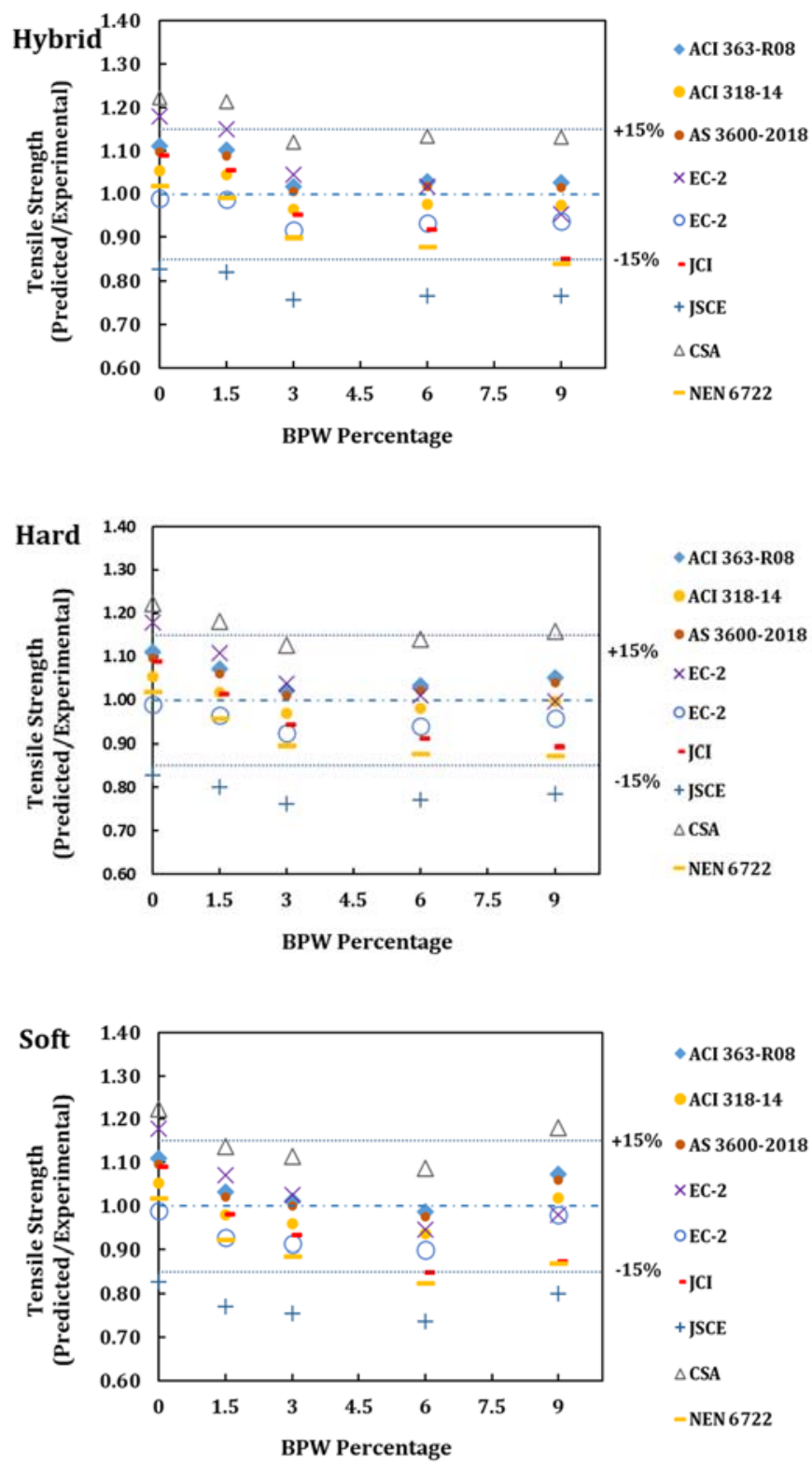

Figure 12. The ratio of predicted tensile strength from different standards for conventional concrete and experimental tensile strength results [16,68-77].

As can be seen, relationships proposed by ACI 363-R08 [68], ACI 318-14 [76], AS 36002018 [16], JCI [71], EC-2 [69] could predict the tensile strength of BPW-containing concrete within $15 \%$ of tolerance. Moreover, several formulae are proposed by other researchers to predict the tensile strength of plastic-containing concrete. The predicted tensile strength ratio, obtained from the proposed equations of other studies, to experimental results of BPW-containing concrete are listed in Table 3 and Figure 13. 

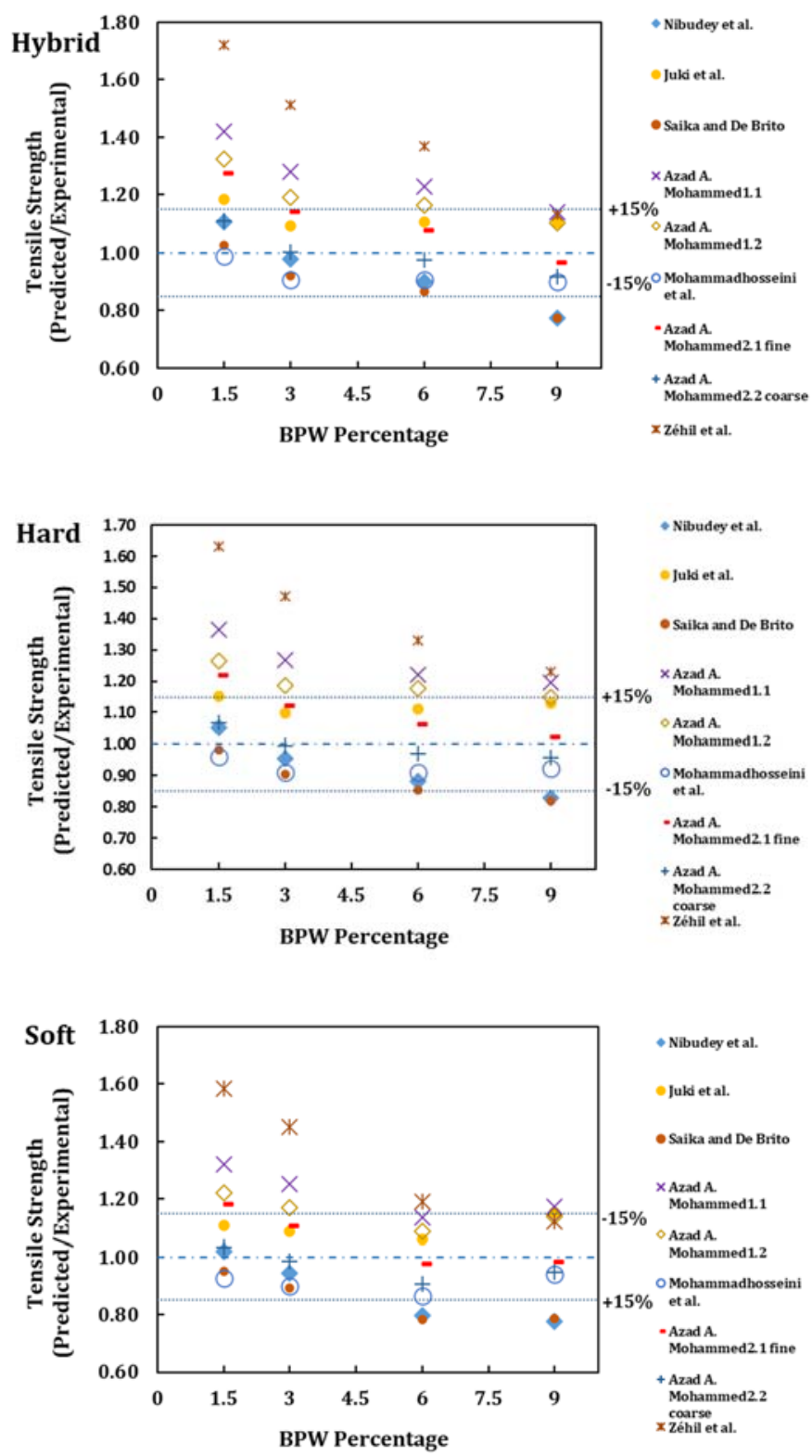

Figure 13. The ratio of predicted tensile strength from other studies for normal strength BPWcontaining concrete, and experimental results [39,50-55].

Among all the predictive formulae, Mohammad (coarse aggregate substitution) [35] and Mohammadhosseini et al.'s [47] formulae could predict all three types of BPWcontaining high-strength concrete within a reasonable tolerance of $15 \%$. The other proposed formulae generally overestimate the tensile strength of BPW-containing high-strength concrete at low BPW percentages and underestimate it at higher percentages.

\subsubsection{Modulus of Elasticity}

The modulus of elasticity ratio of BPW-containing to control concrete versus BPW percentages is shown in Figure 14.

According to the figure, the modulus of elasticity is gradually decreased by the addition of BPW. This phenomenon can be related to the lower modulus of elasticity of BPW compared with aggregate and cement paste. The weaker ITZ can also be another contributing factor for the decline in the concrete's modulus of elasticity after adding more BPW (Figure 7) [18]. Hence, hybrid and hard BPW addition could better maintain the modulus of elasticity due to their higher modulus of elasticity than the soft BPW. 


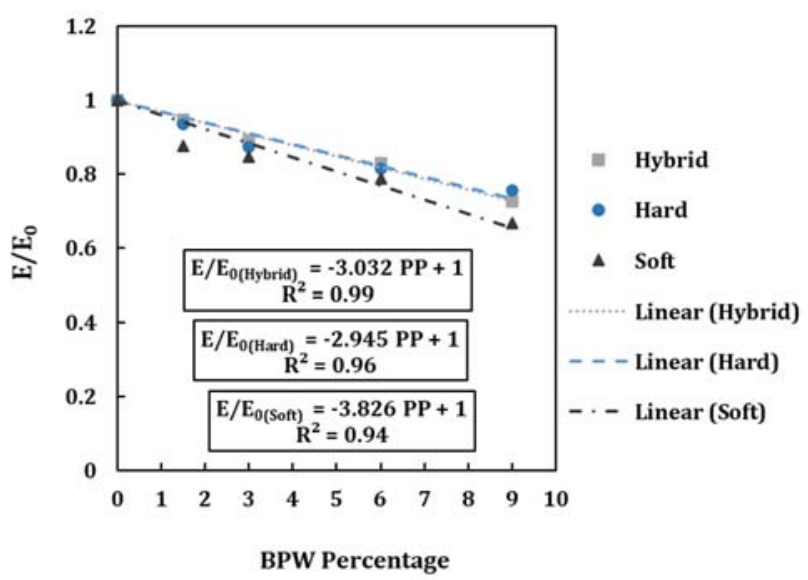

Figure 14. The modulus of elasticity ratio of BPW-containing concrete to control concrete versus BPW percentages.

Moreover, to better understand the behaviour of BPW-containing concrete, the relations between the modulus of elasticity ratio and the density ratio and the compressive strength of $\mathrm{BPW}$-containing concrete to control concrete are investigated and illustrated in Figure 15a, b, respectively.
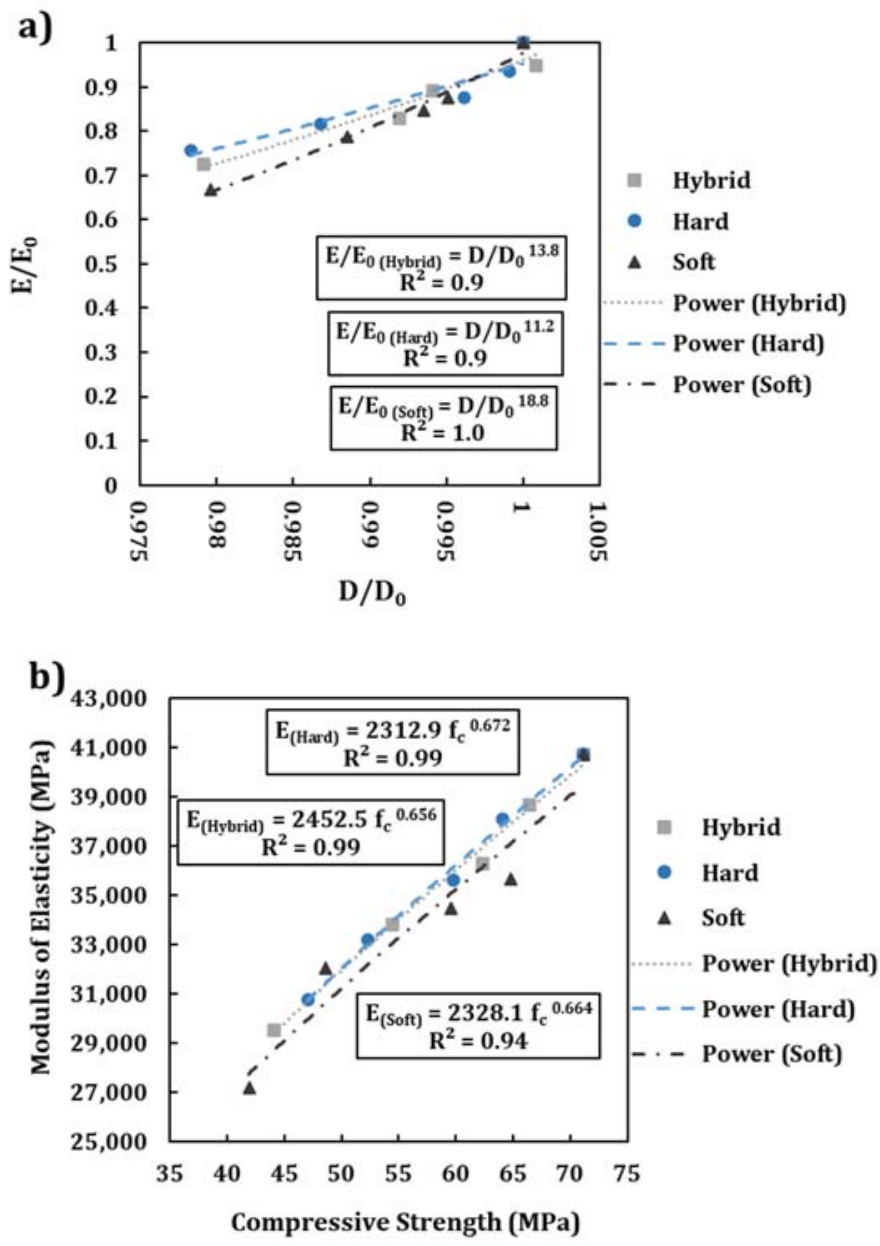

Figure 15. The modulus of elasticity ratio vs: (a) The density ratio of BPW-containing concrete to control concrete, (b) the 28-day compressive strength. 
As expected, the modulus of elasticity decreases by a decrease in the density. It is clear from the figure that the higher the compressive strength, the higher the modulus of elasticity. The relations between the modulus of elasticity and the compressive strength are almost similar and follow the same trend. Hence, to reach simpler formulae and easier engineering interpretations, a general equation for the BPW-containing concrete is introduced with reasonable accuracy, as shown in Figure 16 and Equation (2). As can be seen, the modus of elasticity and the compressive strength of concrete containing BPW follow a power relationship, as suggested in most renowned international codes for conventional concrete.

$$
\mathrm{E}=2469.5\left(\mathrm{f}_{\mathrm{c}}\right)^{\wedge}(0.6526)
$$

In which both $\mathrm{E}$ and $\mathrm{f}_{\mathrm{c}}$ are in $\mathrm{MPa}$.
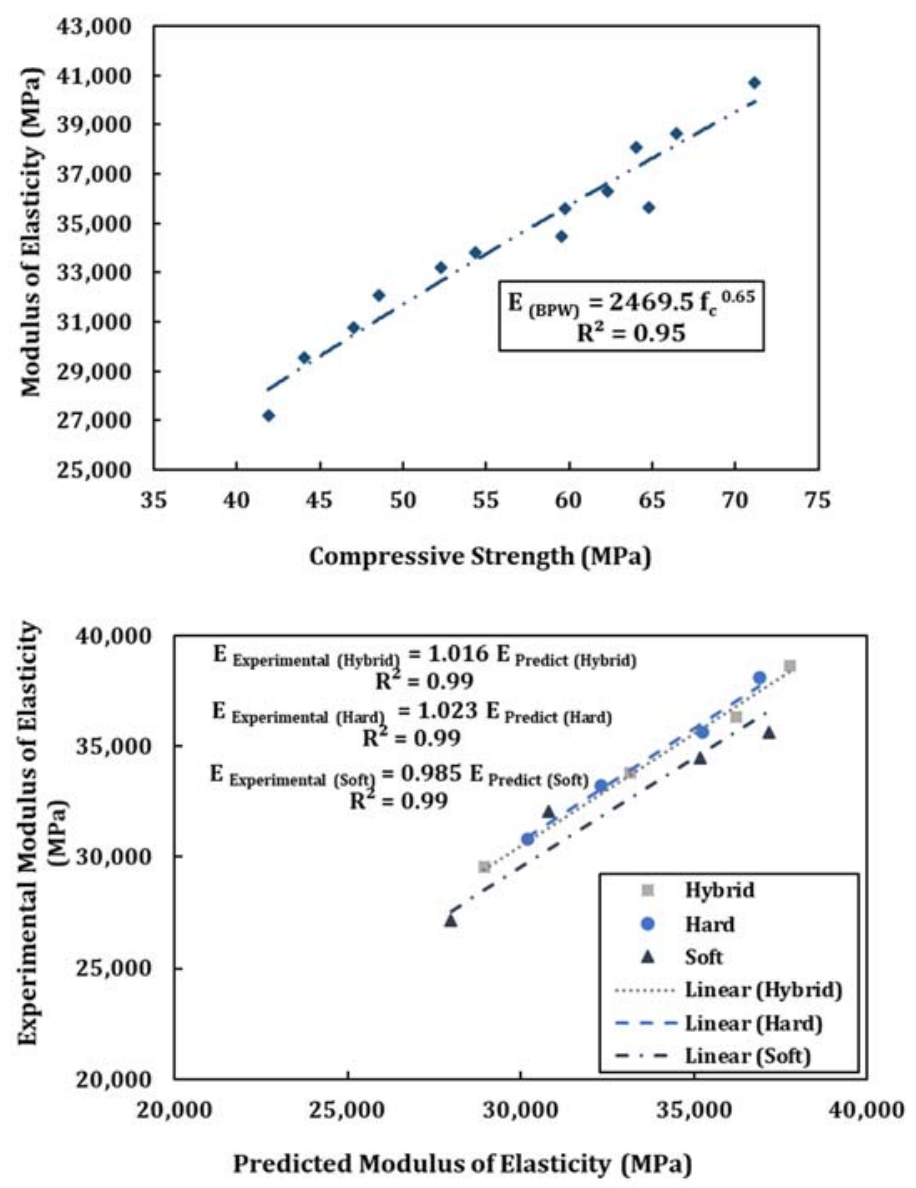

Figure 16. The relation between modulus of elasticity and compressive strength of BPW-containing concrete and correction factors for each type of BPW.

Afterwards, different international codes were investigated to compare the results and investigate if they are still suitable for designing the BPW-containing concrete. In this regard, Figure 17 demonstrates the ratio of predicted modulus of elasticity obtained from the equations proposed by different international codes and the experimental modulus of elasticity results of this study (Table 3). 

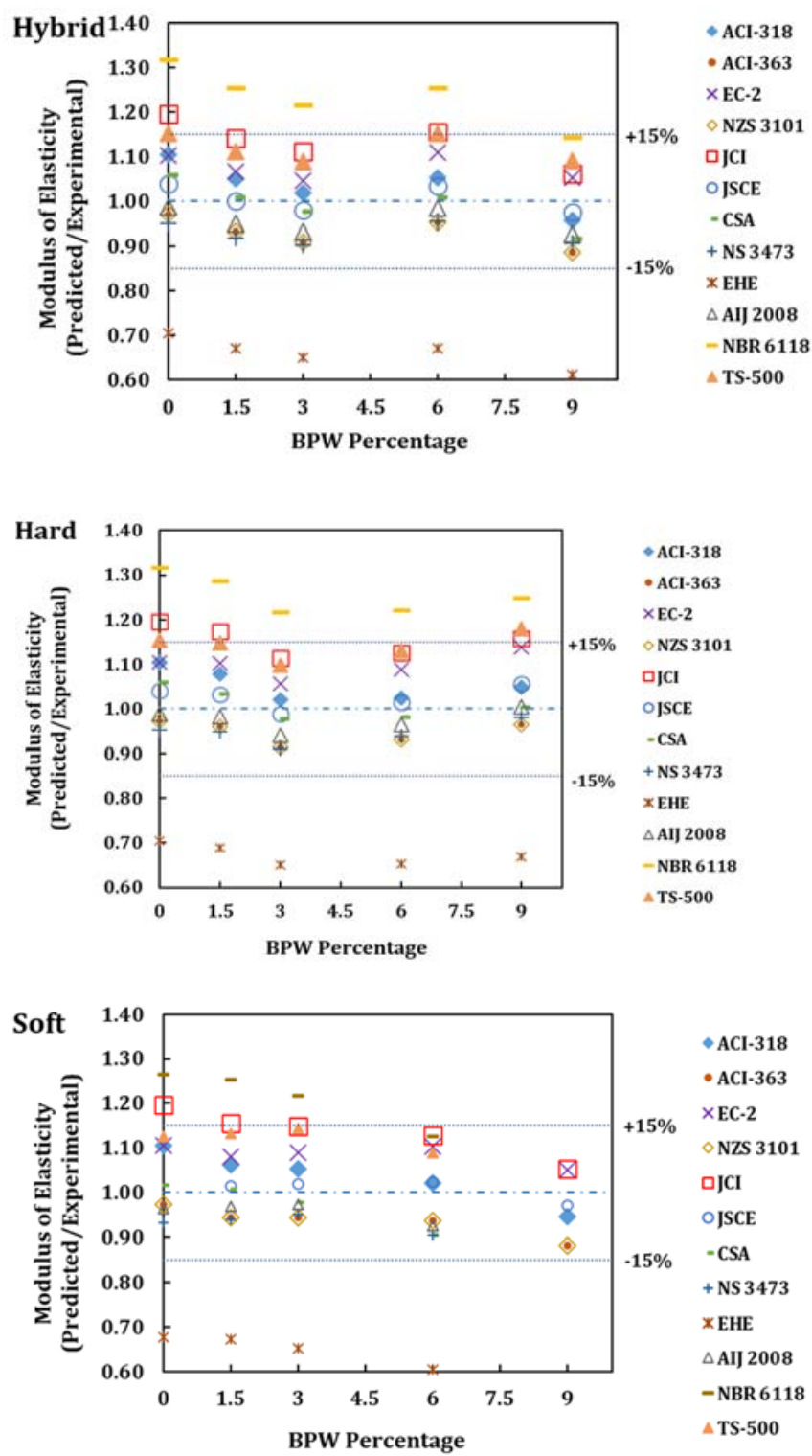

Figure 17. The ratio of predicted modulus of elasticity by the compressive strength from different design codes for conventional concrete and experimental modulus of elasticity results $[16,68,71-74,78-83]$.

It can be concluded that except for JCI [71], EHE [82], NBR 6118 [78], and TS-500 [79], other codes $[68,69,72-74,76,81,82,84]$ could predict the modulus of elasticity of the BPWcontaining concrete within the range of $15 \%$ tolerance.

Some codes also introduced an equation predicting modulus of elasticity from the compressive strength and the conventional concrete's unit weight (Table 3).

Figure 18 illustrates the ratio of the predicted and the experimental modulus of elasticity values for concrete containing different percentages of BPW. As can be seen, ACI 363 [68], NS 3473 [81], and CSA [74] codes can predict the modulus of elasticity of BPW-containing concrete with an error of less than 15\%. AS 3600 [16] predictions also fall in a reasonable range, except regarding concrete containing $9 \%$ of soft BPW. 

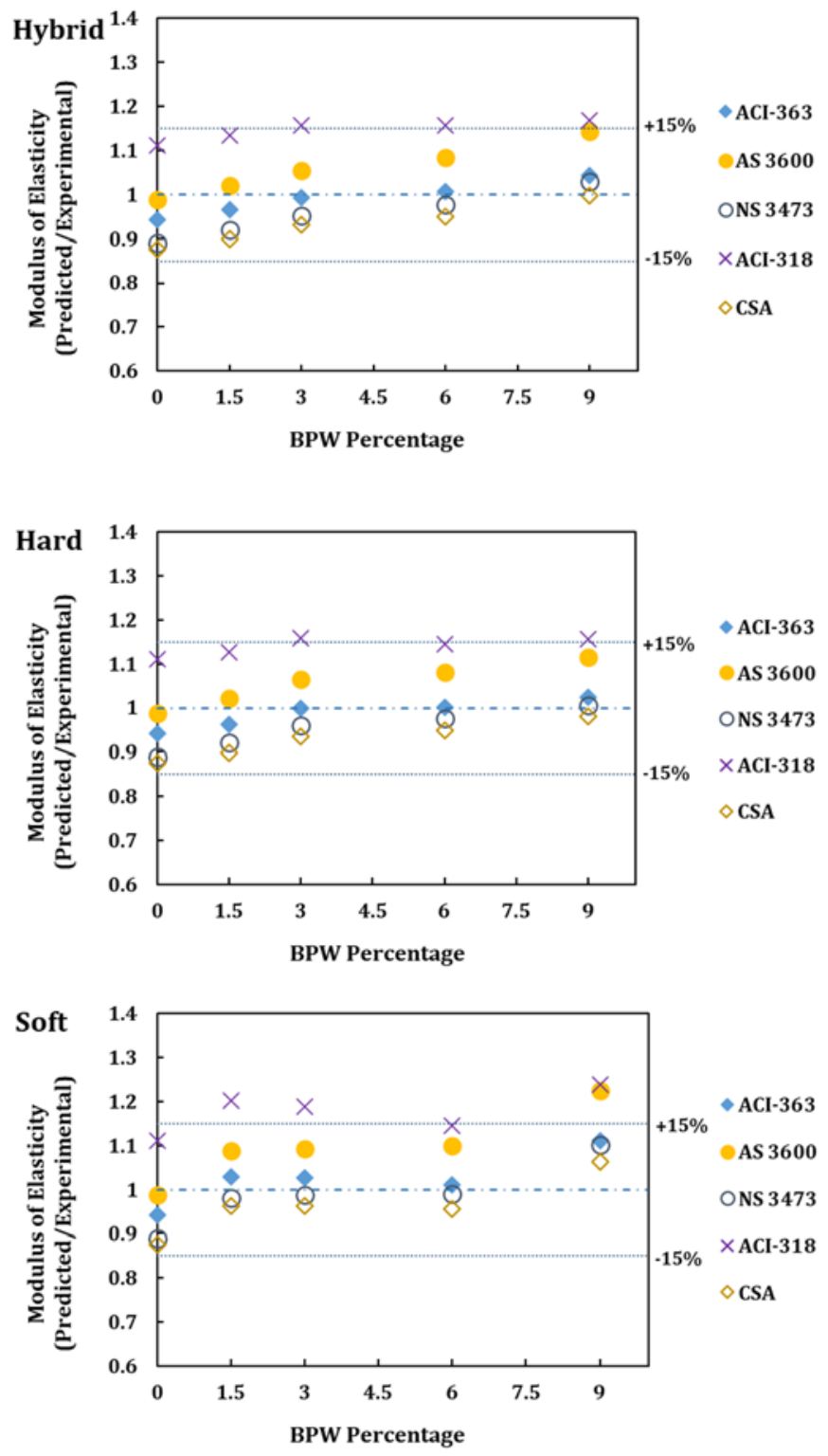

Figure 18. The ratio of predicted modulus of elasticity by the compressive strength and unit weight from different design codes for conventional concrete and experimental modulus of elasticity results $[16,68,74,76,81]$.

The obtained experimental modulus of elasticity values were then compared with calculated values based on equations proposed by other researchers for plastic-containing concrete, as shown in Figure 19 and Table 3. 

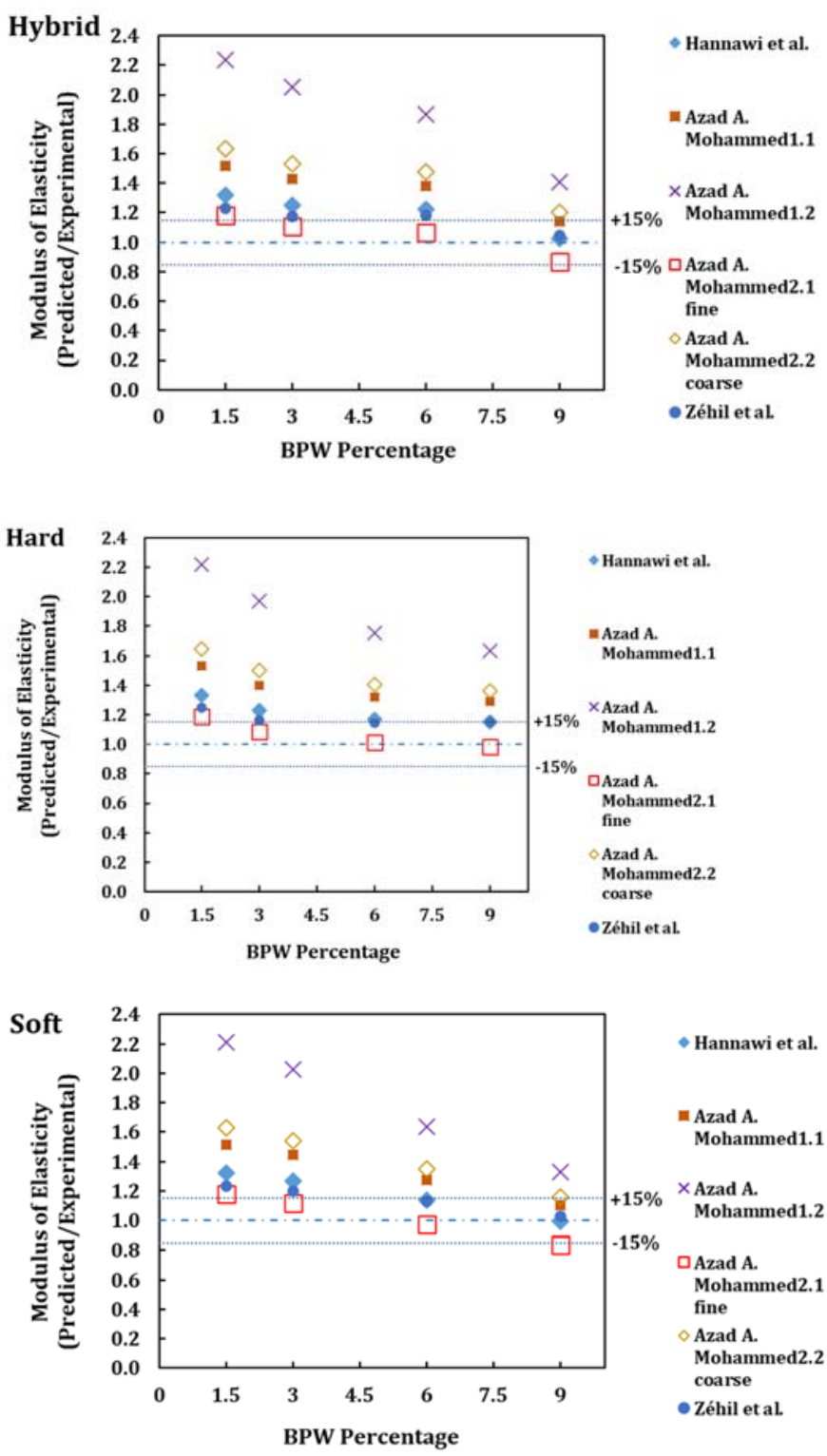

Figure 19. The ratio of predicted modulus of elasticity by the introduced formulae of other studies for BPW-containing concrete, and experimental results [39,42,50,51].

Mohammad's [35] formula regarding fine-aggregate partial substitution with

Polyvinyl chloride (PVC) aggregate could predict the modulus of elasticity of all three types of BPW-containing high-strength concrete within a reasonable tolerance. Although, it marginally overestimates the modulus of elasticity of $1.5 \% \mathrm{BPW}$-containing concrete. It is clear that all other formulae considerably overestimate the modulus of elasticity of BPW-containing high-strength concrete. 
Table 3. Proposed models introduced by international codes and other researchers regarding the tensile strength and modulus of elasticity prediction of BPW-containing concrete.

\begin{tabular}{|c|c|c|c|}
\hline Code & \multicolumn{3}{|c|}{ Proposed Equations $\left(E, f_{c}\right.$, and $f_{t}$ Are in $\left.\mathrm{MPa}\right)$} \\
\hline ACI 363-R08 [68] & $\mathrm{f}_{\mathrm{t}}=0.59\left(\sqrt{ }\left(\mathrm{f}_{\mathrm{c}}\right)\right)^{\mathrm{b}}$ & $E=3320 \sqrt{ }\left(f_{c}\right)+6900^{b}$ & $\begin{aligned} E= & \left(3320 \sqrt{ }\left(f_{c}\right)+6900\right) \times \\
& (D / 2346)^{\wedge}(3 / 2)^{b}\end{aligned}$ \\
\hline ACI 318-14 [76] & $\mathrm{f}_{\mathrm{t}}=0.56\left(\sqrt{ }\left(\mathrm{f}_{\mathrm{c}}\right)\right)^{\mathrm{a}}$ & $\mathrm{E}=4700 \sqrt{ }\left(\mathrm{f}_{\mathrm{c}}\right)^{\mathrm{a}}$ & $\mathrm{E}=\mathrm{D}^{\wedge}(1.5) \times 0.043 \sqrt{ }\left(\mathrm{f}_{\mathrm{c}}\right)^{\mathrm{a}}$ \\
\hline AS 3600-2018 [16] & $\mathrm{f}_{\mathrm{t}}=0.9 \times 0.36\left(\sqrt{ }\left(\mathrm{f}_{\mathrm{c}}\right)\right)^{\mathrm{a}, \mathrm{b}}$ & - & $\mathrm{E}=(\mathrm{D})^{\wedge}(1.5) \times\left(0.024 \sqrt{ }\left(\mathrm{f}_{\mathrm{c}}\right)+0.12^{\mathrm{a}, \mathrm{b}}\right.$ \\
\hline $\mathrm{EC}-2[69]$ & $\mathrm{f}_{\mathrm{t}}=1 / 3\left(\mathrm{f}_{\mathrm{c}}-8\right)^{\wedge}(2 / 3)^{\mathrm{a}}$ & $\mathrm{E}=(22 / 0.001) \times\left(\mathrm{f}_{\mathrm{c}} / 10\right)^{\wedge}(0.3)^{\mathrm{a}, \mathrm{b}}$ & - \\
\hline EC-2 [69] & $f_{t}=2.12 \times \ln \left(1+0.1 f_{c}\right)^{b}$ & - & - \\
\hline $\mathrm{JCI}[71]$ & $f_{t}=0.13\left(f_{c}\right)^{\wedge}(0.85)^{a}$ & $E=(6.3 / 0.001) \times\left(f_{c}\right)^{\wedge}(0.45)^{a}$ & - \\
\hline JSCE [72] & $\mathrm{f}_{\mathrm{t}}=0.44\left(\mathrm{f}_{\mathrm{c}}\right)^{\wedge}(0.5)^{\mathrm{a}}$ & $E=(9 / 0.001) \times\left(f_{c}\right)^{\wedge}(1 / 3)^{a}$ & - \\
\hline CSA [74] & $\mathrm{f}_{\mathrm{t}}=0.65\left(\sqrt{ }\left(\mathrm{f}_{\mathrm{c}}\right)\right)^{\mathrm{a}}$ & $\mathrm{E}=4500 \sqrt{ }\left(\mathrm{f}_{\mathrm{c}}\right)^{\mathrm{a}}$ & $E=3300 \sqrt{ }\left(f_{c}\right)+6900(D / 2300)^{\wedge}(1.5)^{a}$ \\
\hline NEN $6722[75]$ & $\mathrm{f}_{\mathrm{t}}=1+0.05\left(\sqrt{ }\left(\mathrm{f}_{\mathrm{c}}\right)\right)^{\mathrm{a}}$ & - & - \\
\hline NZS [73] & - & $E=3320 \sqrt{ }\left(f_{c}\right)+6900^{a}$ & $\mathrm{E}=9500 \mathrm{f}_{\mathrm{C}}{ }^{\wedge}(0.3) \times(\mathrm{D} / 2300)^{\wedge}(1.5)^{\mathrm{a}}$ \\
\hline NS 3473 [81] & - & $E=9500\left(f_{c}\right)^{\wedge}(0.3)^{a}$ & - \\
\hline EHE [82] & - & $E=10,000\left(3 \sqrt{ }\left(f_{c}\right)\right)^{a}$ & - \\
\hline AIJ 2008 [83] & - & $\mathrm{E}=(8.56 / 0.001)\left(\mathrm{f}_{\mathrm{c}}\right)^{\wedge}(1 / 3)^{\mathrm{a}}$ & - \\
\hline NBR [78] & - & $E=5600 \sqrt{ }\left(f_{c}\right)^{a}$ & - \\
\hline TS-500 [79] & - & $E=3250 \sqrt{ }\left(f_{c}\right)+14,000^{a}$ & - \\
\hline Nibudey et al. [50] & $f_{t}=0.105 f_{c}-0.758$ & - & - \\
\hline Juki et al. [49] & $f_{t}=0.634\left(f_{c}\right)^{\wedge}(0.5)$ & - & - \\
\hline Saikia and Brito [48] & $\mathrm{f}_{\mathrm{t}}=0.086 \mathrm{f}_{\mathrm{c}}-0.0783$ & - & - \\
\hline Mohammad [46] 1.1 & $\mathrm{f}_{\mathrm{t}}=0.713+0.0826 \mathrm{f}_{\mathrm{c}}$ & $E=1.694+0.807 f_{c}$ & - \\
\hline Mohammad [46] 1.2 & $f_{t}=0.246\left(f_{c}\right)^{\wedge}(0.75)$ & $E=0.229\left(f_{c}\right)^{\wedge}(1.4)$ & - \\
\hline $\begin{array}{c}\text { Mohammadhosseini } \\
\text { et al. [47] }\end{array}$ & $f_{t}=0.0499 f_{c}+1.6704$ & - & - \\
\hline $\begin{array}{l}\text { Mohammad [35] } \\
2.1 \text { fine }\end{array}$ & $\mathrm{f}_{\mathrm{t}}=0.0838 \mathrm{f}_{\mathrm{c}}-0.0106$ & $E=0.9078 f_{c}-0.8023$ & - \\
\hline $\begin{array}{l}\text { Mohammad [35] } \\
2.2 \text { coarse }\end{array}$ & $f_{t}=0.06 f_{c}-0.86$ & $E=0.661 f_{c}-0.877$ & - \\
\hline Zéhil and Assaad [45] & $\mathrm{f}_{\mathrm{t}}=0.144 \mathrm{f}_{\mathrm{c}}-2.043$ & $E=0.478 f_{c}+12.98$ & - \\
\hline Hannawi et al. [38] & - & $E=4.6886+0.6534 f_{c}$ & - \\
\hline
\end{tabular}

Considering all of the above-mentioned information and the relationships proposed between $\mathrm{E}, \mathrm{f}_{\mathrm{c}}$, and $\mathrm{D}$ in several international codes, as shown in Table 3, an equation with high accuracy of more than $95 \%$ was obtained using regression analysis based on the experimental data obtained in this study to predict the modulus of elasticity of the BPW-containing concrete (Figure 20), as:

$$
\mathrm{E}=\left(0.043 \sqrt{ }\left(\mathrm{f}_{\mathrm{c}}\right)-0.046\right) \times \mathrm{D}^{\wedge} 1.5
$$

where the $\mathrm{f}_{\mathrm{c}}$ and $\mathrm{E}$ are in $\mathrm{MPa}$ and $\mathrm{D}$ is in $\mathrm{kg} / \mathrm{m}^{3}$. 

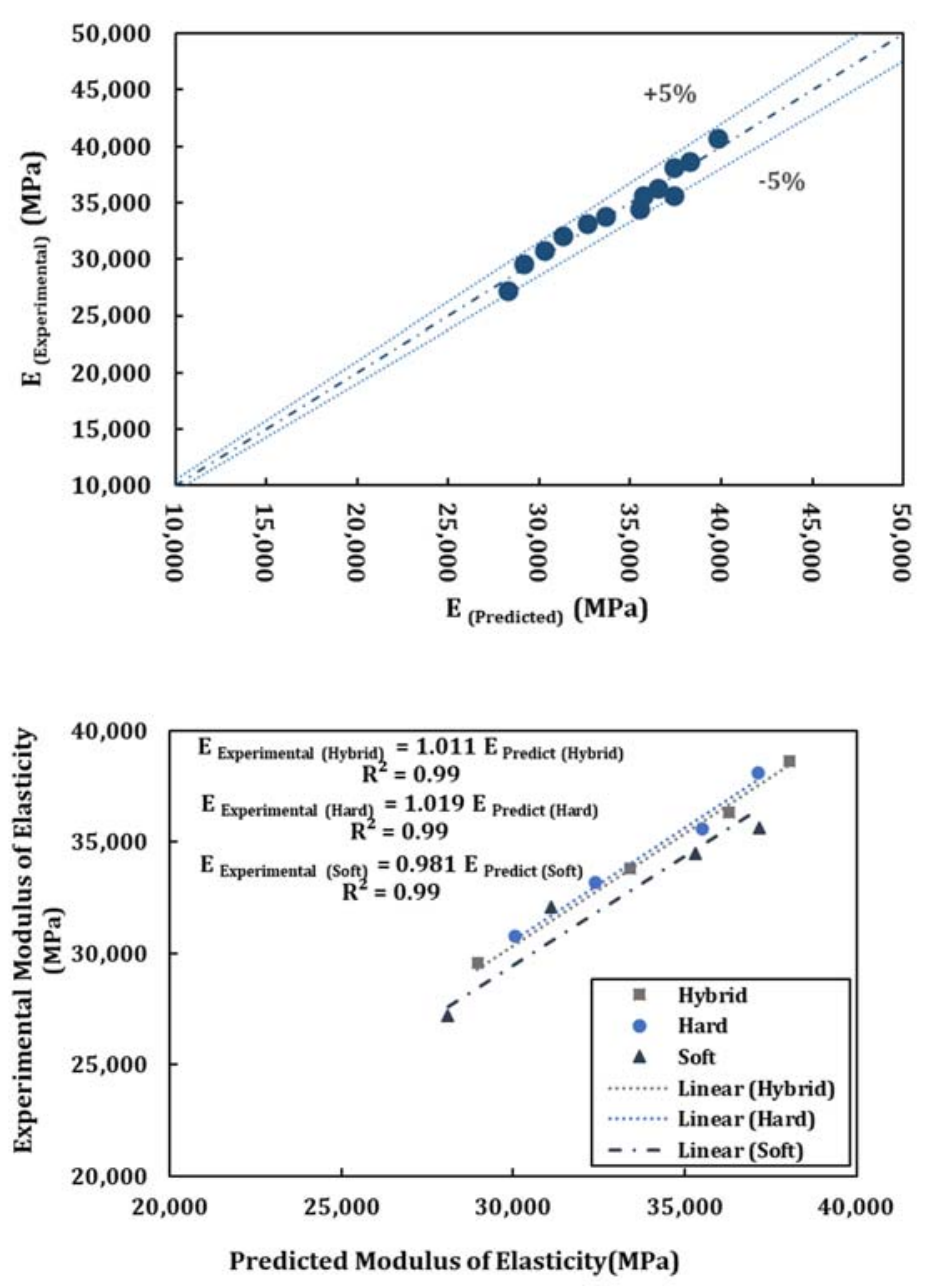

Figure 20. Experimental modulus of elasticity of the concrete containing BPW versus predicted values obtained from the Equation (3), and correction factors for each type of BPW.

\section{Conclusions}

This paper reported the results of an experimental study conducted to investigate and evaluate fresh and hardened properties of high-strength concrete containing three types of BPW, hybrid, hard, and soft, to address a current lack of knowledge of employing this concrete for engineering purposes and pave the way towards the utilisation of biomedical waste in structural concrete as a sustainable way of their disposal. The following main concluding remarks can be drawn:

- Generally, including hard or hybrid BPW in concrete results in better properties than soft BPW-containing concrete.

- The more BPW addition leads to more reduction in the slump by up to $46.4 \%, 54.4 \%$, and $48.8 \%$ after adding up to $9 \%$ hybrid, hard, and soft BPW, respectively. It can be attributed to the flaky and elongated shapes of the BPW particles, affecting the workability factors due to more friction and lower flowability.

- Incorporating BPW causes the density of the concrete to decrease by up to $2.08 \%$, $2.17 \%$, and $2.04 \%$ regarding hybrid, hard, and soft BPW, respectively.

- The compressive strength of all types of BPW-containing high-strength concrete is lower than the non-BPW-containing concrete, which can be attributed to a weaker cohesion and friction at the ITZ of BPW and the cement paste compared to the natural aggregate. The compressive strength declines gradually by BPW addition up to $9 \%$ hybrid, hard, and soft BPW by $38.08 \%, 33.9 \%$, and $41.16 \%$, respectively. 
- The tensile strength of the BPW-containing concrete decreases by adding more BPW by up to $14.9 \%, 14.16 \%$, and $20.62 \%$ for hybrid, hard and soft BPW, respectively. However, at small amounts of BPW addition, the tensile strength reduction is marginally the same as the non-BPW-containing concrete.

- Addition of BPW leads the modulus of elasticity to decrease by up to $27.41 \%, 24.4 \%$, and $33.19 \%$ for hybrid, hard, and soft BPW-containing concrete respectively, which can be attributed to the lower modulus of elasticity of the DWP than natural aggregate and more porous ITZ between the BPW and the cement paste.

- The structural and physical properties of BPW-containing concrete generally follow the same models used in most conventional concrete codes, i.e., a power relationship is observed between $\mathrm{f}_{\mathrm{t}}$ and $\mathrm{f}_{\mathrm{c}}$, and $\mathrm{E}$ and $\mathrm{f}_{\mathrm{c}}$. Predictions by ACI 363-R08 [68], ACI 318-14 [76], AS 3600-2018 [16], and EC-2 [69] are better matched with the results of this study.

- Comparing with other formulae proposed for the tensile strength of plastic-containing concrete, results of this study are in good agreement with Mohammadhosseini et al. [19] and Mohammad (coarse aggregate substitution) [35]. However, they utilised quite different types and shapes of polymeric materials.

- Given the difficulties involved in measuring the modulus of elasticity, and following several codes $[16,68,74,76,81]$, a regression-based formula was proposed to predict the elastic modulus of BPW-containing concrete based on its density and compressive strength.

Given that the essential mechanical properties of structural concrete containing a small percentage of hybrid BPW are predictable by current codes for normal concrete, and noting that preparing hybrid BPW does not need any manual procedure, adding BPW in concrete seems to be a viable solution to decrease the landfilling problem caused by medical waste.

Author Contributions: S.R.: Methodology, Investigation, Writing-Original Draft; K.G.: Supervision, Writing-Review and Editing; E.O.G.: Supervision, Writing-Review and Editing; R.A.-A.: Supervision, Writing-Review and Editing. All authors have read and agreed to the published version of the manuscript.

Funding: This research received no external funding.

Institutional Review Board Statement: Not applicable.

Informed Consent Statement: Not applicable.

Acknowledgments: Authors gratefully acknowledge John Agar (Barwon Health), Katherine Barraclough (Melbourne Health), and Fresenius Medical Care support for providing the dialysis polymeric waste. We also acknowledge Deakin University's support and assistance of the Structures and Materials laboratories technicians.

Conflicts of Interest: The authors declare that they have no known competing financial interests or personal relationships that could have influenced the work reported in this paper.

\section{References}

1. Birchard, K. Out of sight, out of mind ... the medical waste problem. Lancet 2002, 359, 56. [CrossRef]

2. Mohee, R. Medical wastes characterisation in healthcare institutions in Mauritius. Waste Manag. 2005, 25, 575-581. [CrossRef] [PubMed]

3. Mbongwe, B.; Mmereki, B.T.; Magashula, A. Healthcare waste management: Current practices in selected healthcare facilities, Botswana. Waste Manag. 2008, 28, 226-233. [CrossRef]

4. Dormer, A.; Finn, D.P.; Ward, P.; Cullen, J. Carbon footprint analysis in plastics manufacturing. J. Clean. Prod. 2013, 51, 133-141. [CrossRef]

5. Zamora-Castro, S.A.; Salgado-Estrada, R.; Sandoval-Herazo, L.C.; Melendez-Armenta, R.A.; Manzano-Huerta, E.; Yelmi-Carrillo, E.; Herrera-May, A.L. Sustainable Development of Concrete through Aggregates and Innovative Materials: A Review. Appl. Sci. 2021, 11, 629. [CrossRef]

6. Jain, A.; Siddique, S.; Gupta, T.; Jain, S.; Sharma, R.K.; Chaudhary, S. Evaluation of concrete containing waste plastic shredded fibers: Ductility properties. Struct. Concr. 2020. [CrossRef] 
7. Ohemeng, E.A.; Ekolu, S.O. Strength prediction model for cement mortar made with waste LDPE plastic as fine aggregate. J. Sustain. Cem. Mater. 2019, 8, 228-243. [CrossRef]

8. Anandan, S.; Alsubih, M. Mechanical Strength Characterization of Plastic Fiber Reinforced Cement Concrete Composites. Appl. Sci. 2021, 11, 852. [CrossRef]

9. Wu, Y.; Song, W.; Zhao, W.; Tan, X. An experimental study on dynamic mechanical properties of fiber-reinforced concrete under different strain rates. Appl. Sci. 2018, 8, 1904. [CrossRef]

10. Piccoli, G.B.; Nazha, M.; Ferraresi, M.; Vigotti, F.N.; Pereno, A.; Barbero, S. Eco-dialysis: The financial and ecological costs of dialysis waste products: Is a "cradle-to-cradle" model feasible for planet-friendly haemodialysis waste management? Nephrol. Dial. Transplant. 2015, 30, 1018-1027. [CrossRef]

11. Windfeld, E.S.; Brooks, M.S.-L. Medical waste management-A review. J. Environ. Manag. 2015, 163, 98-108. [CrossRef] [PubMed]

12. Jang, Y.-C.; Lee, C.; Yoon, O.-S.; Kim, H. Medical waste management in Korea. J. Environ. Manag. 2006, 80, 107-115. [CrossRef] [PubMed]

13. Klangsin, P.; Harding, A.K. Medical waste treatment and disposal methods used by hospitals in Oregon, Washington, and Idaho. J. Air Waste Manage. Assoc. 1998, 48, 516-526. [CrossRef]

14. Schecter, A.; Birnbaum, L.; Ryan, J.J.; Constable, J.D. Dioxins: An overview. Environ. Res. 2006, 101, 419-428. [CrossRef] [PubMed]

15. Wolfe, M.F.; Schwarzbach, S.; Sulaiman, R.A. Effects of mercury on wildlife: A comprehensive review. Environ. Toxicol. Chem. Int. J. 1998, 17, 146-160. [CrossRef]

16. Standards Australia. Concrete Structures; AS 3600-2018; Standards Australia: Sydney, NSW, Australia, 2018.

17. American Concrete Institute. Building Code Requirements for Structural Concrete (ACI 318-11) and Commentary; American Concrete Institute: Farmington Hills, MI, USA, 2011; ISBN 9780870317446.

18. Rahmani, E.; Dehestani, M.; Beygi, M.H.A.; Allahyari, H.; Nikbin, I.M. On the mechanical properties of concrete containing waste PET particles. Constr. Build. Mater. 2013, 47, 1302-1308. [CrossRef]

19. Batayneh, M.; Marie, I.; Asi, I. Use of selected waste materials in concrete mixes. Waste Manag. 2007, 27, 1870-1876. [CrossRef]

20. Ismail, Z.Z.; Al-Hashmi, E.A. Validation of using mixed iron and plastic wastes in concrete. In Proceedings of the Second International Conference on Sustainable Construction Materials and Technologies, Ancona, Italy, 28 June 2010; pp. $393-403$.

21. Rai, B.; Rushad, S.T.; Kr, B.; Duggal, S.K. Study of waste plastic mix concrete with plasticizer. ISRN Civ. Eng. 2012, 2012. [CrossRef]

22. Soroushian, P.; Plasencia, J.; Ravanbakhsh, S. Assessment of reinforcing effects of recycled plastic and paper in concrete. Mater. J. 2003, 100, 203-207.

23. Janfeshan Araghi, H.; Nikbin, I.M.; Rahimi Reskati, S.; Rahmani, E.; Allahyari, H. An experimental investigation on the erosion resistance of concrete containing various PET particles percentages against sulfuric acid attack. Constr. Build. Mater. 2015, 77, 461-471. [CrossRef]

24. Nikbin, I.M.; Rahimi, S.; Allahyari, H. A new empirical formula for prediction of fracture energy of concrete based on the artificial neural network. Eng. Fract. Mech. 2017, 186, 466-482. [CrossRef]

25. Rahimi, S.; Nikbin, I.M.; Allahyari, H.; Habibi, S. Sustainable approach for recycling waste tire rubber and polyethylene terephthalate (PET) to produce green concrete with resistance against sulfuric acid attack. J. Clean. Prod. 2016, 126, 166-177. [CrossRef]

26. Jain, A.; Siddique, S.; Gupta, T.; Jain, S.; Sharma, R.K.; Chaudhary, S. Fresh, strength, durability and microstructural properties of shredded waste plastic concrete. Iran. J. Sci. Technol. Trans. Civ. Eng. 2019, 43, 455-465. [CrossRef]

27. Ghernouti, Y.; Rabehi, B.; Bouziani, T.; Ghezraoui, H.; Makhloufi, A. Fresh and hardened properties of self-compacting concrete containing plastic bag waste fibers (WFSCC). Constr. Build. Mater. 2015, 82, 89-100. [CrossRef]

28. Al-Hadithi, A.I.; Hilal, N.N. The possibility of enhancing some properties of self-compacting concrete by adding waste plastic fibers. J. Build. Eng. 2016, 8, 20-28. [CrossRef]

29. Marthong, C.; Sarma, D.K. Influence of PET fiber geometry on the mechanical properties of concrete: An experimental investigation. Eur. J. Environ. Civ. Eng. 2016, 20, 771-784. [CrossRef]

30. Kandasamy, R.; Murugesan, R. Fibre reinforced concrete using domestic waste plastics as fibres. ARPN J. Eng. Appl. Sci. 2011, 6, 75-82.

31. Alhozaimy, A.M.; Shannag, M.J. Performance of concretes reinforced with recycled plastic fibres. Mag. Concr. Res. 2009, 61, 293-298. [CrossRef]

32. Yang, S.; Yue, X.; Liu, X.; Tong, Y. Properties of self-compacting lightweight concrete containing recycled plastic particles. Constr. Build. Mater. 2015, 84, 444-453. [CrossRef]

33. Saikia, N.; de Brito, J. Mechanical properties and abrasion behaviour of concrete containing shredded PET bottle waste as a partial substitution of natural aggregate. Constr. Build. Mater. 2014, 52, 236-244. [CrossRef]

34. Albano, C.; Camacho, N.; Hernandez, M.; Matheus, A.; Gutierrez, A. Influence of content and particle size of waste pet bottles on concrete behavior at different $\mathrm{w} / \mathrm{c}$ ratios. Waste Manag. 2009, 29, 2707-2716. [CrossRef]

35. Mohammed, A.A.; Mohammed, I.I.; Mohammed, S.A. Some properties of concrete with plastic aggregate derived from shredded PVC sheets. Constr. Build. Mater. 2019, 201, 232-245. [CrossRef]

36. Manjunath, B.T.A. Partial replacement of e-plastic waste as coarse-aggregate in concrete. Procedia Environ. Sci. 2016, 35, 731-739. [CrossRef] 
37. Alqahtani, F.K.; Ghataora, G.; Dirar, S.; Khan, M.I.; Zafar, I. Experimental study to investigate the engineering and durability performance of concrete using synthetic aggregates. Constr. Build. Mater. 2018, 173, 350-358. [CrossRef]

38. Hannawi, K.; Kamali-Bernard, S.; Prince, W. Physical and mechanical properties of mortars containing PET and PC waste aggregates. Waste Manag. 2010, 30, 2312-2320. [CrossRef]

39. Mathew, P.; Varghese, S.; Paul, T.; Varghese, E. Recycled plastic as coarse aggregate for structural concrete. Int. J. Innov. Res. Sci. Eng. Technol. 2013, 3, 687-690.

40. Choi, Y.W.; Moon, D.J.; Kim, Y.J.; Lachemi, M. Characteristics of mortar and concrete containing fine aggregate manufactured from recycled waste polyethylene terephthalate bottles. Constr. Build. Mater. 2009, 23, 2829-2835. [CrossRef]

41. Won, J.-P.; Jang, C.-I.; Lee, S.-W.; Lee, S.-J.; Kim, H.-Y. Long-term performance of recycled PET fibre-reinforced cement composites. Constr. Build. Mater. 2010, 24, 660-665. [CrossRef]

42. Camilo, J.R.; Rohden, A.B.; Garcez, M.R. Concrete with rejected recyclable plastic waste at high temperatures. Mag. Concr. Res. 2020, 1-15. [CrossRef]

43. Záleská, M.; Pavlikova, M.; Pokorný, J.; Jankovský, O.; Pavlík, Z.; Černý, R. Structural, mechanical and hygrothermal properties of lightweight concrete based on the application of waste plastics. Constr. Build. Mater. 2018, 180, 1-11. [CrossRef]

44. Ruiz-Herrero, J.L.; Nieto, D.V.; López-Gil, A.; Arranz, A.; Fernández, A.; Lorenzana, A.; Merino, S.; De Saja, J.A.; Rodríguez-Pérez, M.Á. Mechanical and thermal performance of concrete and mortar cellular materials containing plastic waste. Constr. Build. Mater. 2016, 104, 298-310. [CrossRef]

45. Zéhil, G.-P.; Assaad, J.J. Feasibility of concrete mixtures containing cross-linked polyethylene waste materials. Constr. Build. Mater. 2019, 226, 1-10. [CrossRef]

46. Mohammed, A.A. Modelling the mechanical properties of concrete containing PET waste aggregate. Constr. Build. Mater. 2017, 150, 595-605. [CrossRef]

47. Mohammadhosseini, H.; Tahir, M.M.; Sam, A.R.M. The feasibility of improving impact resistance and strength properties of sustainable concrete composites by adding waste metalized plastic fibres. Constr. Build. Mater. 2018, 169, 223-236. [CrossRef]

48. Saikia, N.; Brito, J. de Waste polyethylene terephthalate as an aggregate in concrete. Mater. Res. 2013, 16, 341-350. [CrossRef]

49. Juki, M.I.; Awang, M.; Annas, M.M.K.; Boon, K.H.; Othman, N.; Roslan, M.A.; Khalid, F.S. Relationship between compressive, splitting tensile and flexural strength of concrete containing granulated waste polyethylene terephthalate (PET) bottles as fine aggregate. In Proceedings of the Advanced Materials Research; Trans Tech Publications: Zurich, Switzerland, 2013; Volume 795, pp. 356-359.

50. Nibudey, R.N.; Nagarnaik, P.B.; Parbat, D.K.; Pande, A.M. Strengths prediction of plastic fiber reinforced concrete (M30). Int. J. Eng. Res. Appl. 2013, 3, 1818-1825.

51. Fresenius Medical Care Australia. Available online: https:/ / www.fmc-au.com/ (accessed on 25 February 2021).

52. Agar, J.; Barraclough, K.; Al-Ameri, R. DIalysis plastic waste recycled as a concrete incorporative. In Proceedings of the Nephrology; John Wiley \& Sons: Hoboken, NJ, USA, 2018; Volume 23, p. 39.

53. Standards Australia. Methods for Sampling and Testing Aggregates Method 11.1: Particle Size Distribution-Sieving Method; AS 1141-2009; Standards Australia: Sydney, NSW, Australia, 2009.

54. Standards Australia. AS 2758 Aggregates and Rock for Engineering Purposes; Standards Australia: Sydney, NSW, Australia, 2009.

55. Standards Australia. General Purpose and Blended Cements; AS 3972-2010; Standards Australia: Sydney, NSW, Australia, 2010.

56. ACI Committee 211. Standard Practice for Selecting Proportions for Normal, Heavyweight, and Mass Concrete (Reapproved 2009); ACI 211.1-91; ACI: Farmington Hills, MI, USA, 2009; Available online: https://www.concrete.org/store/productdetail.aspx?ItemID= 211191 (accessed on 29 October 2015).

57. Standards Australia. Methods of Testing Concrete-Method for Making and Curing Concrete—Compression and Indirect Tensile Test Specimens AS 1012.8.1:2014; Standards Australia: Sydney, NSW, Australia, 2014.

58. Standards Australia. Methods of Testing Concrete—Determination of Properties Related to the Consistency of Concrete-Slump Test AS 1012.3.1:2014; Standards Australia: Sydney, NSW, Australia, 2014.

59. Geo-Con Products. Available online: https://www.geo-con.com.au/product/general-utility-compression-frames / (accessed on 2 February 2021).

60. Standards Australia. Methods of Testing Concrete—Determination of Mass per Unit Volume of Hardened Concrete—Rapid Measuring Method AS 1012.12.1-1998; Standards Australia: Sydney, NSW, Australia, 1998.

61. Standards Australia. Methods of Testing Concrete—Compressive Strength Tests—Concrete, Mortar and Grout Specimens AS 1012.9:2014; Standards Australia: Sydney, NSW, Australia, 2014.

62. Standards Australia. Methods of Testing Concrete Determination of Indirect Tensile Strength of Concrete Cylinders ("Brasil" or Splitting Test); AS 1012.10-2000 (R2014); Standards Australia: Sydney, NSW, Australia, 2014.

63. Standards Australia. Determination of the Static Chord Modulus of Elasticity and Poisson's Ratio of Concrete Specimens; AS 1012.171997; Standards Australia: Sydney, NSW, Australia, 2014.

64. JEOL Ltd. Available online: https:/ /www.jeol.co.jp/en/products/detail/JSM-IT300.html (accessed on 25 February 2021).

65. Reis, J.M.L.; Chianelli-Junior, R.; Cardoso, J.L.; Marinho, F.J.V. Effect of recycled PET in the fracture mechanics of polymer mortar. Constr. Build. Mater. 2011, 25, 2799-2804. [CrossRef]

66. Kou, S.C.; Lee, G.; Poon, C.S.; Lai, W.L. Properties of lightweight aggregate concrete prepared with PVC granules derived from scraped PVC pipes. Waste Manag. 2009, 29, 621-628. [CrossRef] 
67. Choi, Y.-W.; Moon, D.-J.; Chung, J.-S.; Cho, S.-K. Effects of waste PET bottles aggregate on the properties of concrete. Cem. Concr. Res. 2005, 35, 776-781. [CrossRef]

68. ACI Committee 363. 363R-08 Report on High-Strength Concrete; American Concrete Institute: Farmington Hills, MI, USA, 2008.

69. European Commitiee for Standardization. Design of Concrete Structures; BS EN 1992-1-1; European Commitiee for Standardization: Brussels, Belgium, 2004.

70. American Association of State Highway and Transportation Officials. AASHTO Interim Bridge Design Specifications and Commentary; American Association of State Highway and Transportation Officials: Washington, DC, USA, 2006.

71. Japan Concrete Institute. Guidelines for Control of Cracking of Mass Concrete 2008; Japan Concrete Institute: Tokyo, Japan, 2008.

72. Japan Society of Civil Engineers. Standard Specifications for Concrete Structures; Japan Society of Civil Engineers: Tokyo, Japan, 2007; ISBN 9784810607529.

73. Standards New Zealand. NZS 3101: Concrete Structures Standard-The Design of Concrete Structures; Standards New Zealand: Wellington, New Zealand, 2006.

74. Canadian Standards Association (CSA). Design of Concrete Structures; A23.3-04; Canadian Standards Association: Toronto, ON, Canada, 2004.

75. The Royal Netherlands Standardization Institute Regulations Concrete Construction; 6722; Netherlands Standards: Delft, The Netherlands, 2000.

76. American Concrete Institute 318-14. Building Code Requirements for Structural Concrete (ACI 318-14) Commentary on Building Code Requirements for Structural Concrete (ACI 318R-14); ACI: Farmington Hills, MI, USA, 2014.

77. The International Federation for Structural Concrete. Fib Model Code for Concrete Structures 2010; John Wiley \& Sons: Hoboken, NJ, USA, 2013.

78. Brazilian Association of Technical Standards. Design of Structural Concrete; NBR 6118; Brazilian Committee for Civil Construction: Rio Janeiro, Brazil, 2003.

79. Turkish Standards Institute. Requirements for Design and Construction of Reinforced Concrete Structures; TS-500; Turkish Standards: Ankara, Turkey, 2000.

80. Comite Euro-Inernational Du Beton. CEB-FIP Model Code 1990; Design code; Telford: Geneva, Switzerland, 1993 ; ISBN 0727716964.

81. Norwegian Council for Strandardization. Concrete Structures—Design Rules; NS 3473; Norwegian Council for Strandardization: Oslo, Norway, 1992.

82. Spanish Ministry of Public Works. Spanish Code for Structural Concrete; EHE; Real Decreto 2661; Spanish Ministry of Public Works: Madrid, Spain, 1998.

83. Architectural Institute of Japan. Recommendations for Practice of Thermal Cracking Control of Massive Concrete in Building; Architectural Institute of Japan: Tokyo, Japan, 2008.

84. Architectural Institute of Japan. AIJ Standard for Structural Design of Reinforced Concrete Boxed-Shaped Wall Structures; Architectural Institute of Japan: Tokyo, Japan, 2002. 